\title{
Modern Library Facilities to Enhance Learning in a Teachers' College
}

\author{
B. O. Awana
}

\begin{abstract}
This paper examines modern facilities for enhance teachers Education. A brief definition of the library was made well as attempt at what the objectives of an academic library should be. The concept, Education was examined and a brief but concise analysis of teacher education was also looked at. Modern facilities/Equipments in the library that can aid effective utilization of the resources of the library were discussed. A brief summary was also made.
\end{abstract}

\section{Introduction}

Education can simply be defined as what we learn from cradle to grave. This can be done through formal education which is organized through the classroom situation with an instructor/teacher directing or in an informal context where we acquire the education by imitation or learning through the process of "doing it yourself".

NCCE (1992) quoted by Isyaku (2002) sees education as a process that involves the efforts of a person, called the teacher, imparting, or trying to impart knowledge, information, skill, value, attitudes or whatever, to another person or group of persons assumed to be relatively inexperienced and unskilled, in a manner that is morally acceptable and pedagogically efficient. It further defined education as "a deliberate and organized effort to initiate the learner into thinking and behaving as well as into a core of norms, values, skills and techniques considered desirable for developmental purposes in the society. 
Whawo (1994) sees teacher education as representing specially designed professional training programmes for people who opt for teaching job. Adesina, Fagbongbe and Talabi (1995) quoted in Whawo (1994) see teacher education as that aspect of education which deals with the acquisition of practical and applied skills in the teaching profession. Okafor (1988) quoted in Whawo (1994) defined teacher education as "that programming instruction which is properly planned and systematically tailored and applied for the cultivation of those of teachers or who will teach particularly, but not inclusively in primary and post primary level of schooling. In its extended dimension, it encourages also the preparation of administrators, supervisors and guidance counselors. The ordinary reason is to help teachers help youths under their tutelage to achieve maximum knowledge in minimum time under the given conditions.

Fafunwa (1967) is of the view that teacher education should basically be related to every phase of development in Africa. Wherever the directions, be in the social, economic or political sphere of activities, is faced with the ever recurring problems of the need for trained manpower, but no adequate training can take place without competent teachers to handle the programmes. Stressing the importance of teacher education further, Fafunwa (1974) states that the National Policy on Education reaffirmed that teacher education will continue to be given a major emphasis in all educational planning because no education system can rise above the quality of its teachers.

For teacher education to be successful, functional and effective, it must be backed up by a good and functional library, where the informational materials/media stocked, are capable of helping the clientele to be able to retrieve needed information/materials that will fit their teaching/learning 
research at any given time. Landau (1966) describes the library as a collection of books and other forms of records, housed, organized and interpreted to meet the broad and varying needs of the people for education, information, research, e.t.c. therefore books alone do not form the content of a library, the books must be arranged and the library must meet the needs of their users.

Teachers who are supposed to impart knowledge and influence on other people need good education. The library is the agency that is solely devoted to do that. (Awana (1997) quoting Ralph C. Conant (1992). Well stocked library with current and up-to-date materials is indispensable, while modern facilities for generating, storing and disseminating information in libraries becomes very essential.

\section{Objectives of Academic Libraries.}

The objectives of the academic library do not end with the provision of materials for academic pursuit of its immediate clientele alone but should also provide materials that are so expensive and out of reach of those who may wish to use them. The library shall contain materials that are of special and general interest to its clientele especially great works in science, technology and literature. It should meet the specialized information needs of the users. Okiy (1999 \& 2000) states that "the main reason why libraries exist is to provide the right materials to meet the information needs of their users". Oyesiku and Akinbode (2004) quoting Ifidon (1985) said that the major objective of the African University is to provide materials and services which will now and in the future contribute to the fulfillment of the objectives for students and staff and even members of the public for their course work, essays, term-paper, projects, thesis, dissertation, research and personal development. Also the 200 
objective of any library is to provide organized information materials for effective utilization since it stocks a variety of books, journals and other documents in different subjects areas., format and media. According to an academic library's main objective is to acquire, organize and disseminate to users instructional materials without which teaching, learning and research become ineffective. Aina (2004) states that the main purpose of a university library is to support the objective of a university, is in the area of teaching, research and service. Mabawonku (1992) points out that academic libraries exist for the benefit of students and teacher. In order to function and serve the information needs of users, the library needs to have both print and electronic materials like CDROM data base, e-journals, internet, e.t.c. Clarke (1999) pointed out in a general manner, that library objectives are the provision of information, stimulation of education, research, recreational facilities, promotion of cultural activities and the preservation of recorded knowledge of man.

The tripartite functions of academic institutions especially, the university is to conserve the existing knowledge, to transmit the knowledge through research by rationally and systematically accumulation of all kinds of human communication and records published or unpublished, written or oral in recorded form, that incorporates the ideas and knowledge of the past.

The effectiveness or success of an academic library is measured by the effective utilization of its resources. The indispensability of a good library and the importance of books can be seen from the remarks of Emerson Greens ways; president of America Library Association (A.L.A) 1958-1959. States 
The world of books is the most remarkable creation of man; nothing else that he builds ever last. Monuments fall, nations perish, civilization grow old and die out, and after an era of darkness, new races build up. But in the world of books are volumes that have seen these happen again and again and yet live on, still young, still as fresh as the day they were written, still telling man's heart of hearts".(Awana 2004).

Books tell the story of history of the past, conserve the present and prepare the way for the future. Library is not only the heart of the institution it is established, but also the nerve center of all academic pursuit. Abdulkadir (1995) cited by Mohammed (1996) observed that the central focus of any educational institution is its library. It is the hub of the system to which both the students and staff resort to for academic nourishments. Thus, an up-to-date library contributes in no small measure to paving the way for academic excellence. The library is a recognized and essential resources centre which no student can afford to dispense with, if he want to attain his academic goal. The library has a major influence in the learning process, providing the individual with opportunities of learning how to discover through self directed study, to refill and to up date ones knowledge to reassure people of even what we know, to learn new facts and ideas and to fulfill a particular need.

Orgeron (2005) while stressing the usefulness of the academic library states that "the library is a very natural component to academic support services now complementing tutoring, career decision making and writings across the curriculum". The functions of the academic library show how 
important it is in the educational process. An adequate functional library is not only aimed at meeting the teaching and study needs of the patrons, but also to meet the essential conditions of research, without which there may be no additions human knowledge. The library obviously supports the institution in the process of developing an inquiring mind. Ray (1990), described the library as a repository of knowledge and that no meaningful teachinglearning and research can take place without it. Also the library is regarded as the house of knowledge. It is the "nerve centre" of educational institution and that is why researchers who are involved in teaching, learning and research should be conversant and exposed to the library to know how to use the resources of the library with minimal difficulty.

\section{Availability of Infrastructural Facilities and Equipment.}

Infrastructural facilities/equipment are those items or services in the library that will help to achieve the effectiveness in the services rendered by the library. The library is a store house of knowledge.

Ifidon (1985) opined that the main objective of academic library is to provide materials and services to meet the objectives of the university. A well equipped library is very necessary in all institutions of learning so that immediate references can be made when the need arises.

Line (1971) notes that the function of the library is to bring information and knowledge and human beings together. He regretted that libraries under utilized due to the fact that they lack the necessary facilities, equipment and conduciveness. Other equipments that would be useful in the library and may lead to good patronage of such libraries include photocopying machines, indexing and abstracting 
services, internet facilities, etc. It has been proved sufficiently that the availability of functional photocopying services have gone a long way to reduce the incidence of theft or vandalisation of library materials to the barest minimum. Uwem (2004).

Access to the documents in the libraries is made possible and easier to users through the various catalogues in the libraries which serve as indexes to the library holdings, (Akande 2003). It is essential to provide catalogues to users of he library, for easy reference In another related users' study in Nigerian academic libraries. Osinulu (2003) quoting Adelani (1998) and Odusanya (2001) argued that majority of students are not skilled in the use of catalogue as an information retrieval tool. Their findings also showed that information searching through manual library catalogue consumed time. However, Akande (2003) affirms that usage of electronic database aids easy access and reduces the time spent while searching for materials compared to traditional services method. Availability of Information Technology (I.T) has revolutionized operations and services. Indexing and abstracting services are very necessary for the accessibility of the library stock. Users should be taught how to use the library catalogues to find needed materials in the library, using the author, title or subject catalogues. The main function of any library is to provide services that will enhance research and scholarship. The catalogue is very vital to the existence of the library since it serves as an information storage and retrieval tool. If a library user does not know that with the aid of the catalogue the materials needed will be easily located on the shelf a great deal of time will be wasted browsing. In a research conducted by Ifidon (1977) on the use of divided or dictionary catalogue, it was revealed that the attitude of undergraduate students' use of the catalogue 
was not encouraging at the early stage in their career but increases with the passage of time. Akande (2003) in a survey of the use of a university library noted as regards the use of the catalogue that any difficulty in the use of catalogue can be a major barrier between the students and the library resources. Out of the total respondents of 413,114 or $34.9 \%$ use the catalogue with difficulty, 42 or $10.2 \%$ would not use it if they could avoid it, while 257 or 54.9 found the catalogue very useful.

Indexes and abstracts are other forms of infrastructure in the library that are useful to users. These are surrogates of real documents. They are vital tools for the creation of current awareness of the library's new resources especially journal-based information. An index does not provide the information needed, it indicates where it can be found by regularly listing articles that appear in different journals in a given field; Madu and Adeniran (2000). And abstract goes further to attempt a summary of the article in such a way that enables the user to decide whether to consult the work or not. Essentially, indexes and abstracts are bridges to the main information resumes. (Uwem 2003). Similarly, Oyovwe (2004) opined that it is essential for special libraries to render indexing and abstracting services to its users in order to satisfy the needs for information. Ejimkonye (1991) described index as a systematically arranged list giving enough information about each document to make it possible and easy for it to be identified and traced. He described abstract as a summary of a publication or article accompanied by an adequate bibliographic description to enable the publication or article to be traced.

The reprographic section helps patrons by making available facilities and equipment to handle photocopying, duplication and mimeographing. While the bindery section 
makes sure that repaired mutilated materials (as a result of heavy use on demand and which could be easily replaced) are sent back to the open shelves for the reader's usage.

An internet service in the library is another good facility that can help library users source information. With the rapid emergence of cyber-café in every corner, researchers can search information from their homes or offices, it must be stated clearly here that with the advent of information communication technology (I.C.T) scheme and the librarian will still be relevant in the scheme of thing. The librarian will not be thrown out of job as observed by Martin (1996) who noted that the role of the brokers just like that of the librarian is often questioned in our society. He opined.

why use a real estate agent? You can sell your own house yourself. Why a lawyer for a will?. You can write your own will. Why go to a doctor? You can just walk into a chemist shop to buy your drugs. Why go to school? You can teach yourself

There is no more complex part of the world today than the information environment, and it too, requires brokers. Librarians are information brokers and information seekers will increasingly need their services. They may however, be rename as "information professional or information scientist". Librarians too should strive to keep abreast with the new information technologies by constantly updating themselves through seminars, workshops, induction courses, e.t.c. 


\section{Electronic Resources and Effective Utilization of Academic Libraries.}

As a result of the growth in information Communication Technology (ICT) Nigerian libraries are being computerized, especially the academic libraries. World wide web resources are organized in such a way that users can easily move from one resources to another. Ogunsola (2004) opined that digitalization is gradually taking place and most libraries are being connected to the internet. The National Virtual Library Project is an initiative of the Federal Ministry of Education. The mission of the project is to provide in an equitable and cost effective manner, enhanced access to national and international libraries and information resources and for sharing locally available resources with libraries all over the world using digital technology. Ajibero (2004) said that internet has become an invaluable tool for learning, teaching and research. The Internet is dramatically changing the world of research and teaching as it is with the virtual library, which is used to describe libraries in which computers and telecommunication technologies make access to a wide range of information resources possible. It is often referred to as "digital library", electronic library" or "library without walls". It is called "virtual" because in a good electronic wide area network library, the user enjoys the euphoria of being in distant libraries and yet he has not physically moved. Internet has greatly reduced and eased the problem of getting information for research in all spheres of lives or fields. The internet may reduce over-reliance on the library. Today, the internet is the largest global communications network in history. 
Some of the advantages of ICT include the following.

- It allows easy integration of various activities; various works and services in the library become better coordinated

- It facilitates co-operation and the formation of library network. This can be done through the Local Area Network (LAN)

- It increases efficiency in the information of duties and services delivery in the library system.

For any academic library to perform well and meet the needs of the users on this modern time, it is necessary for the academic library to embrace the use of information and communication technology. Mordi (2005) citing Henderson (1992) states that I.T provides numerous benefits and advantages to library users some of the advantages which include.

$>$ Provision of speedy and easy access to information

$>$ Provision of remote access to users

$>$ Provision of access to unlimited information from different sources and

$>$ Provision of information flexibility to be used by any individual.

On academic libraries and the use of ICT by students Olanlokun and Tiamigh (1982) have this to say "things that were done manually in the past are now done using computers and communication technologies. Technology has become a blessing in the generation, packaging and utilization of information by information seekers, and librarians should braze up to the new challenges. In a survey conducted by Ojo and Akande (2005) to know how students use the electronic information resources, it was gathered that students use internet more. This is followed by e-main. Other electronic information resources used by students in the order 208 
of importance include CD-ROM, e-Journal, OPAC. A lot of academic information can be received using the resources both inside and outside of the library. This may be the reason why they are more popular than other resources. Asked where they normally go to access electronic information resources, some of them say cyber café, while other say they use the internet in the library, others use the internet in their parents' offices.

The major obstacle to ICT in academic libraries is that of funding as the venture is capital intensive. It requires a lot of money to keep it going. On issue of fund and I.T., Ikem and Ajala (2000) quoted by Ugulu (2004) noted that the problem of funding is the major constraint of I.T. in libraries. They opined that the problem of funding is more than just acquiring the hardwares and softwares but updating and maintenance are very crucial in order to sustain their workability and efficiency. With the advent of the e-library which is computer -based and the appropriate softwares and with proper interface with the systems, library operations, information and retrieval and information utilization will be faster, less stressful and strenuous, current and easy

When these items discussed above are put in place in a library and properly implemented, teacher education would be promoted and enhanced tremendously.

\section{Recommendation/Conclusion}

The following recommendations are hereby made:

- Up- to- date informational materials should be provided in the academic libraries for the use of the clientele. The materials so provided should be well organized and made accessible to the potential users.

- Academic library operations should be computerized for better performance 
- For proper utilization of resources in the library, especially the internet facilities, computer literacy for both staff and library users should be emphasized so that users can explore the possibilities of effectively using the internet.

\section{References}

Aina, I.O.(2004) Library and Information Science text for Africa. Ibadan: the World Information Services Ltd. Ajibero, M.I.(2004) "Donor Support and Sustainability: the Experience of University Libraries in Nigeria" Unpublished papers of standing conference of Africa University libraries Western Area(SCAULWA) held at Erata hotel, Accra, Ghana.

Akande,S.O.(2003) Pattern of First Year Students Use of the University Library: A survey at the University of Ibadan. Lagos Journal of Library \& Information Science Vol. 2 (i) pp.22-26.

Akinbode,R.O.(1996) "University Library Services and Information needs of Students and Staff in an Academic Community" Le professor Vol 4 pp 41-42. Eriksson, J. (2005) "Information Resources for the Academic Community on the Internet". The electronic library to information. File:/ (A:) The electronic librarygateway to information paper. Eriksson htm.

Ifidon, S.E (1999) Essentials of African University Library Management. Lagos: The national Library Pr.

Ikem, J. E. and Ajala E.E (2000) "Some Development In Library" Information Technology at the Kenneth Dike Information Technology in Library and Information Science Education in Nigeria. Fayose P.O \& Nwalo 
K.I.N. (eds): NALISIS pp 27- 28

Line, $p(1971)$ "The Functions of the Library". Journal of Oyo State of Nigeria Library Association (N.L.A). Vol 54) pp. 18-24 London: Macmillan.

Mabawonku, I (1992) "Deterrents to the Use of Instructional Media in Nigerian Universities". African Journal of Library Archives \& Information Science Vol. 2 (2) pp. 26-32.

Martin, J.R (1996) transforming the Academic Library: an Interview. University of Southern Mississippi

Mordi, V.N. (2005) " Impact of Information Communication technology (ICT) in University Libraries". A Study of Edo and Delta Libraries. Unpublished M.Sc (L.I.S) Dissertation. DELSU, Abraka.

Ogunsola, L.A (2004) "Nigerian University Libraries and the Challenges of Globalization: the way Forward". Electronic Journal of Academic and Special Librarianship. Vol. 5 (2 \&3) fall Pp 1 of 10

Ojo, R.A. and Akande, S.O (2005) "Students Access Usage and Awareness of Electronic Information Resources at the university College Hospital Library, U.I Ibadan". Lagos Journal of Library \& Information science Vol. 3 (1).

Orgeron E (2005) "Integrated Academic students Support Services at Loyola University; the Library as a Resources- clearing house". Journal of Southern Academic \& Special Librarianship file: (A) Orgeron eol. Oyeseku, F.A \& Akinbode, R.O.(2004). A Study on User 
Satisfaction with the Services of Private University Libraries: A case Study of Babcock University Library, Nigeria.

Oyovwe, G.O (2004) "Comparative Study of the Effectiveness of the Libraries of SPDC, NNPC \& chevron oil companies" Upub. M.Sc (L.I.S) dissertation. Delsu, Abraka. Pp 10-24.

Ray C. (1990) "The pastoral of the school library". The School Librarian 31 (2). Pp. 113- 116.

Ugulu, L.O (2004) "The constraints to the use of information Technology in tertiary Institution Libraries in Edo and Delta States of Nigeria:M.Sc dissertation. Unpublished.

URL:http:// w.w.w.lib.edu/library focus/spring 96/spring 961. html.

Uwen, E. (2003) "Readers services at crossroads: Meeting users needs in the Information Age". Lagos Journal of Library and Information Science. Vol 1 (2) pp. 113 119. Vol 3 (1\&2) pp. 59-65.

Whawo, D.D (1994) Planning and teacher Education in Nigeria. Asaba: Alcel concerns. 